的な研究をしていただき，その成果を社会に還元してい ただく，社会との接点を持ってやっていただくというこ とを期待しています。

一ありがとうございました。



今の原子力業界を担う勇者達と いった面々による座談会は大変刺 激的でした。所属や立場が違え ば，こんなにも視点が変わるんだ なと驚かされる一方，日本の原子 カに託す夢やそれに貢献したい気 持ちは共通でした。この日，私自 身が，原子力の仕事をしていくパ ワーをもらった気がしました。今 度は，お酒を飲みながら語り合っ てみたいものです。(石橋)

(取材・編集協力 小林容子編集委員, 佐田務副編集長)
理科少年が仕事を変える，会社

\section{: を救う}

出川 通著，191 p，(2008.5)，彩流社，

（価格1,500円，税別） ISBN 978-4779110320

本書は，自分の専門性を大事にする人を「技術者」として読 者に想定し，素直な関心や遊び心を発想の中心にして新しい ものを作っていこうという呼びかけの本です。「理科少年に は 3 つのタイプがある」,「100点 -99 点 $\neq 1$ 点の法則」, 「不 完全なハイテクに心が躍る」といった魅力的なタイトルの 10 章からなります。各章は理科少年という, 少年の心が躍る「好 奇心と冒険心」から出発していくのですが，そこに技術者と - しての観点と, マネージメントとして, 経営というか世の中 との折り合いのつけ方が次第に入ってきます。この後から 入ってくるところが著者の創意です。

いろいろな議論のなかでも「100点 -99 点 $\neq 1$ 点」の章は, 読むたびに評者の感想や考え方は変わりました。100点の意 味にもいろいろあるから，100点-99点はいつも同じ評価で ・はないのは，そのと扬でしょう。しかし，100点を超えて ・しまった成果は製品としてはオーバースペックで，かえって ・評価が低いかもしれないという発想は，評者には盲点部分で
した。また100点前後の議論のほ か, 0 点前後の議論というのもあ り，これも著者に賛成のときも，反 対したくなるときもありました。

ハイテクーローテクとリスクーリ

ターンの議論もなかなか面白いと感

じます。それが一転して「産学連携 はなぜ難しいか」という話になって くると, 企業の研究者としては「面 白い」ではすまなくて，自分なりに 考えてみなくてはならなくなりま

す。著者の意見に賛成かどうかは重要ではなく，100点前後 の議論と同じく，ここは考えてみるきっかけであると考えれ ばよいのでしょう。

本書の冒頭のほうには，本書は技術者の生き方の話で，真 理の発見を主題にする科学者の生き方は異なると但し書きが あります。理科には技術と科学の萌芽があるのですが，「好 奇心と冒険心」の理科少年はどこでこの二つの生き方に分か れていくのでしょう。ともあれ，どうやら私は技術ではなく 科学の方へ分かれていった少年らしく，本書はあるところま では心をうちますが，あるところからは「そういう考えもあ ろうか」という感想になっていきます。皆様はどうでしょう か。 